\title{
Manajemen Kepemimpinan Inovatif pada Pendidikan Anak Usia Dini dalam Perspektif Merdeka Belajar Era New Normal
}

\author{
Novianty Djafri ${ }^{\circledR}{ }^{凶}$, Arwildayanto $^{2}$, Arifin Suking ${ }^{3}$ \\ Manajemen Pendidikan, Universitas Negeri Gorontalo \\ DOI: $10.31004 /$ obsesi.v5i2.901
}

\begin{abstract}
Abstrak
Penelitian ini dilatarbelakangi oleh adanya temuan kurangnya manajemen kepemimpinan inovatif pada kepala sekolah di tingkat pendidikan anak usia dini. Tujuan penelitian ini adalah untuk mendeskripsikan manajemen kepemimpinan inovatif pada pendidikan anak usia dini dalam perspektif merdeka belajar era new normal di Kota Gorontalo Provinsi Gorontalo. Menggunakan metode penelitian deskriptif kuantitatif. Sumber data terdiri dari 38 orang kepala sekolah. Hasil penelitian menunjukkan bahwa kepemimpinan inovatif kepala sekolah di Kota Gorontalo berada pada kategori baik. Kebaruan yang didapatkan dalam penelitian ini adalah kepala-kepala sekolah di masa datang harus lebih memiliki jiwa revolusioner yang mampu menerima dan mengimplementasikan perubahan melalui visi, misi, dan tujuan untuk mengembangkan sekolah. Dampak dari hasil penelitian ini adalah kepala sekolah perlu bekerjasama bersama tim melalui kreativitas tim dan inovasi organisasi serta cara kerja tersistem dalam inovasi organisasi melalui kreativitas individu secara visual paham akan informasi aktual secara digital untuk mewujudkan merdeka belajar untuk saat ini dan masa depan.
\end{abstract}

Kata Kunci: manajemen; kepemimpinan inovatif; pendidikan; anak usia dini; new normal.

\begin{abstract}
This research is motivated by the findings of a lack of innovative leadership management among principals at the early childhood education level. The purpose of this study is to described innovative leadership management in early childhood education in the perspective of independent learning in the new normal era in Gorontalo City, Gorontalo Province. The method used in this research is quantitative descriptive research method. The data source consisted of 38 school principals. The results showed that the innovative leadership of principals in Gorontalo City was in a good category. The novelty found in this research is that future school principals must have a more revolutionary spirit capable of accepting and implementing change through the vision, mission, and goals of developing schools. The impact of the results of this research is that principals need to work together with the team through team creativity and organizational innovation as well as systemized work methods in organizational innovation through individual creativity visually understanding actual digital information to create independent learning for the present and future.
\end{abstract}

Keywords: management; innovative leadership; education, early childhood; new normal.

Copyright (c) 2020 Novianty Djafri, Arwildayanto, Arifin Suking

$\triangle$ Corresponding author:

Email Address : noviantydjafri@ung.ac.id (Gorontalo, Indonesia)

Received 19 November 2020, Accepted 25 November 2020, Published 28 November 2020 


\section{PENDAHULUAN}

Manajemen kepemimpinan kepala sekolah penting untuk menjadi inovasi pembelajar sebagai kunci keberhasilan merdeka belajar. Pembelajaran pada pendidikan anak usia dini penting untuk metode pembelajaran yang terbaik dalam proses pembelajaran yang efektif. Hal ini tidak lepas dari manajemen kepemimpinan kepala sekolah yang berjiwa inovatif (Utiarahman, 2017). Pada era new normal ini sekolah membutuhkan proses pembelajaran yang dapat menjadikan anak dalam situasi dan kondisi proses pembelajaran yang aman dan kuat imun dan iman dalam menyikapi proses pembelajaran merdeka belajar (Djafri, 2020).

Proses pembelajaran yang inovatif untuk anak tidak serta merta didapatkan oleh setiap anak, hal ini melalui proses pembelajaran yang dari guru yang secara langsung ditransfer oleh guru (Paudi \& Suking, 2020) dan pendidikan dapat menentukan kualitas kehidupan anak di masa mendatang (Fauziddin \& Mufarizuddin, 2018). Hal ini tentunya membutuhkan peran serta seorang kepala sekolah sebagai pemimpin inovatif dalam menginspirasi para guru dalam mempersiapkan konsep pembelajaran yang inovatif (Supriadi, 2020). Kepemimpinan inovatif dapat menjadi roda penggerak untuk proses pembelajar yang efektif di unit sekolahnya, terlebih untuk lingkungan pendidikan anak usia dini. Pendidikan anak usia dini adalah level awal dalam jenjang pendidikan formal, maka untuk konsep proses pembelajaran inovatif sangat penting untuk dikelola dengan baik, melalui pengelolaan yang terstruktur dan terpimpin oleh seorang kepala sekolah (Dewi \& Suryana, 2020; Ideswal et al., 2020).

Kepala sekolah yang memiliki pemikiran pembelajaran yang inovatif penting untuk dapat memberikan ide-ide kreatif dalam pengambilan keputusan yang kompleks untuk menyelesaikan permasalahan unit sekolah dengan aksi yang tepat. Kepala sekolah visioner memiliki visi. Kepala sekolah visioner memiliki visi yang baik untuk organisasi dan kepala sekolah visioner dapat memberikan kesempatan para guru dalam mengadopsi proses pembelajaran yang inovatif dari pemimpinnya, maka dapat memberikan proses pembelajaran yang terampil, aktif, dan efektif terbaik untuk anak didiknya, sehingga luaran sekolah lebih baik walaupun di era new normal ini (Wijoyo \& Indrawan, 2020).

Kepala sekolah inovatif harus dapat membangun inovasi itu penuh dengan resiko kegagalan dan kerugian, serta dapat mengatasi kompleksitas masalah yang harus dihadapi dengan kesabaran dan keberanian dalam mengambil keputusan. Itulah kenapa bahwa kepemimpinan menjadi salah satu bagian terpenting dari lahirnya produk atau layanan yang inovatif (Candra et al., 2020; Yati \& Yaswinda, 2019).

Berdasarkan pentingnya manajemen kepemimpinan yang inovatif maka proses pembelajaran dalam perspektif merdeka belajar pada pendidikan anak usia dini diharapkan dapat memberikan arah perbaikan pada saat kondisi new normal ini sehingga fokus penelitian ini adalah bagaimana pola manajemen kepemimpinan inovatif kepala sekolah dalam perspektif merdeka belajar era new normal di Kota Gorontalo Provinsi Gorontalo sangat urgent untuk dilakukan. Tujuan dari penelitian ini adalah untuk mendeskripsikan manajemen kepemimpinan inovatif pada pendidikan anak usia dini dalam perspektif merdeka belajar era new normal di Kota Gorontalo Provinsi Gorontalo.

Berdasarkan hasil analisis dari penelitian-penelitian sebelumnya, terdapat gap yang cukup tajam mengenai manajemen kepemimpinan ini. Sebagian besar artikel-artikel yang sudah terbit tidak membahas secara spesifik mengenai manajemen kepemimpinan inovatif. Hasil studi pendahuluan yang dilakukan peneliti menemukan bahwa manajemen kepemimpinan yang dibahas pada umumnya hanya manajemen kepemimpinan saja, dan tidak spesifik pada tingkat pendidikan anak usia dini.

\section{METODOLOGI}

Metode penelitian yang digunakan dalam penelitian ini adalah jenis penelitian eksplanatori dengan pendekatan penelitian deskriptif kuantitatif. Desain penelitian bersifat penelitian deskriptif yang dikaji melalui literatur data primer dan data sekunder serta melalui narasi konsep teori dan dipetakan melalui deskriptor indikator yang kemudian datanya 
diolah secara perhitungan kuantitatif melalui angka dan narasi. Bagan arus kegiatan penelitian dapat dilihat pada Gambar 1.

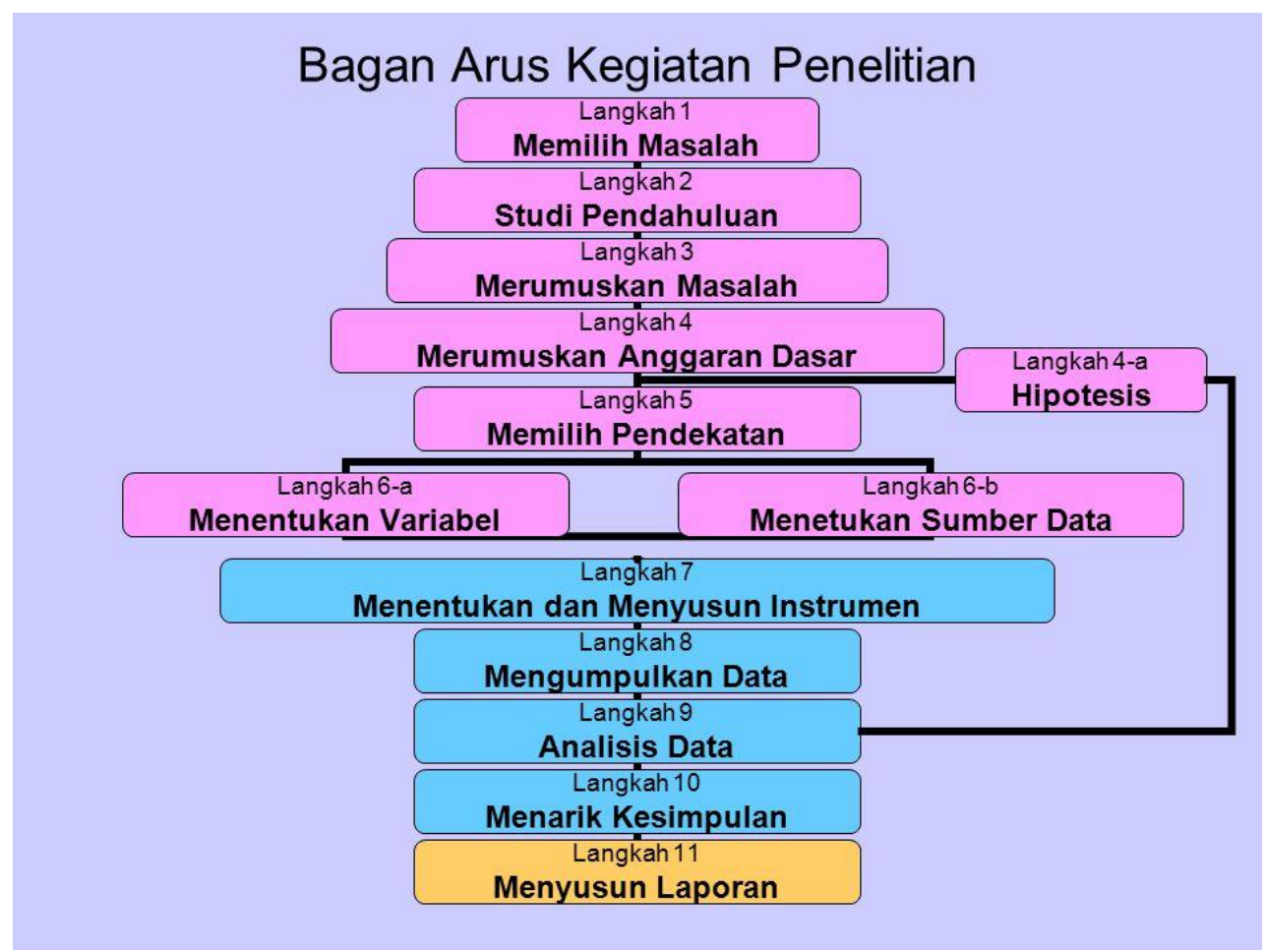

Gambar 1. Bagan Arus Kegiatan Penelitian

(Sumber: (Witarsa \& Dista, 2019))

Tempat penelitian di Pendidikan Anak Usia Dini Kota Gorontalo. Subjek penelitian adalah semua Kepala Sekolah Pendidikan Anak Usia Dini di Kota Gorontalo yang dipilih secara random sampling (acak) yang berjumlah 38 orang. Tehnik Pengumpulan Data yang digunakan melalui observasi, wawancara, dan angket. Teknik analisis data menggunakan analisis deskriptif dalam bentuk tabel frekuensi dengan formula sebagai berikut; pertama, menentukan frekuensi capaian responden untuk setiap butir angket dengan rumus sebagai berikut :

Keterangan

$$
\mathrm{P}=\frac{f}{N} \times 100 \%
$$

$\mathrm{P} \quad=$ Presentase .

$\mathrm{F} \quad=$ Frekuensi.

$\mathrm{N} \quad=$ Jumlah responden.

$100 \%=$ Bilangan tetap.

Selanjutnya langkah kedua, menghitung persentase dalam skor digunakan dalam rumus sebagai berikut:

$$
\operatorname{Pr}=\frac{S A}{S I} \times 100 \%
$$

Keterangan

$\operatorname{Pr} \quad=$ Persentase hasil penelitian .

SA = Skor aktual, yaitu merupakan total skor yang diperoleh seluruh responden.

SI = skor ideal, yaitu jumlah skor maksimum yang bisa dicapai

$100 \%$ = bilangan tetap 
Tabel 1. Kualifikasi Kriteria

\begin{tabular}{ccc}
\hline No. & Rentang Skor $(\%)$ & Kriteria \\
\hline $\mathbf{1}$ & $91-100$ & Sangat Baik \\
$\mathbf{2}$ & $76-90$ & Baik \\
$\mathbf{3}$ & $51-75$ & Cukup Baik \\
$\mathbf{4}$ & $\leq 50$ & Tidak Baik \\
\hline & (Sumber: (Nurdin \& Anhusadar, 2020)).
\end{tabular}

Variabel penelitian ini adalah Manajemen Kepemimpinan Inovatif pada Pendidikan Anak Usia Dini dalam Perspektif Merdeka Belajar Era New Normal di Kota Gorontalo Provinsi Gorontalo. Data diperoleh dari hasil penelitian melalui penyebaran angket berupa butir-butir pernyataan yang disebarkan kepada 38 responden dengan subyek penelitian yaitu kepala sekolah. Data angket tersebut kemudian dianalisis dengan menggunakan analisis persentase yang disajikan melalui tabel persentase. Responden dengan kepemimpinan inovatif dalam perspektif merdeka belajar era new normal di Kota Gorontalo Provinsi Gorontalo ini menggunakan data primer dan sekunder.

Angket tersebut berisi sepuluh pernyataan berdasarkan teori yang dijadikan rujukan dalam penelitian ini. Sepuluh pernyataan tentang manajemen kepemimpinan inovatif dapat diukur sebagai berikut: 1) Persuasif (memiliki gagasan ide kreatif); 2) Komunikati (dapat menyelesaikan hal sulit masalah organisasi); 3) Menginspirasi; 4) Berpikiran terbuka menerima saran dan pendapat; 5) Pembelajar revolusione (mampu menerima dan mengimplementasikan perubahan); 6) Berjiwa evolusione (menerima perubahan dengan caracara baru); 7) Memotivasi tim adaptif perubahan; 8) Bekerjasama memajukan tim; 9) Evaluatif (bekerja tim merancang penilaian pembelajaran); 10) Adaptif teknologi untuk akselarasi merdeka belajar (Mustaghfiroh, 2020).

\section{HASIL DAN PEMBAHASAN}

Angket manajemen kepemimpinan inovatif yang didapatkan dan dideskripsikan yang pertama adalah persuasif, dimana kepala sekolah inovatif yang memiliki ide kreatif. Hal tersebut ditunjukkan pada tabel 2.

Tabel 2. Kepala Sekolah Inovatif yang Memiliki Ide kreatif (Persuasif)

\begin{tabular}{cccccccc}
\hline $\begin{array}{c}\text { Alternatif } \\
\text { Jawaban }\end{array}$ & Bobot & Frekuensi & $\begin{array}{c}\text { Skor } \\
\text { Capaian }\end{array}$ & $\begin{array}{c}\text { Persentase } \\
(\%)\end{array}$ & $\begin{array}{c}\text { Skor } \\
\text { Maksimal }\end{array}$ & $\begin{array}{c}\text { Persentase } \\
\text { Pernyataan }\end{array}$ & Kategori \\
\hline Selalu & 5 & 13 & 65 & 34,21 & & & \\
Sering & 4 & 16 & 64 & 42,11 & & & \\
Kadang & 3 & 9 & 27 & 23,68 & 190 & $82,11 \%$ & Baik \\
Jarang & 2 & 0 & 0 & 23,68 & & & \\
Tidak & 1 & 0 & 0 & 0,00 & & & \\
Pernah & & 38 & 156 & 100,00 & & & \\
Total & & 38 & & & & & \\
\hline
\end{tabular}

(Sumber: Data diolah, 2020)

Tabel 2 menggambarkan bahwa responden yang menyatakan Selalu memiliki frekuensi sebesar 13 atau 34,21\%, responden yang menyatakan Sering memiliki frekuensi sebesar 16 atau $42,11 \%$, responden yang menyatakan Kadang-kadang memiliki frekuensi sebesar 9 atau 23,68\%, sedangkan responden yang menyatakan Jarang dan tidak pernah sebesar 0 atau 0,00\%. Dengan demikian hasil penelitian ini menunjukkan bahwa jawaban sering merupakan pilihan jawaban yang paling banyak dipilih oleh responden yaitu sebanyak $42,11 \%$. 
Dari hasil analisis skor data diatas maka dapat diperoleh persentase $82,11 \%$, jika dilihat dari Tabel 2 diatas bahwa kepala sekolah inovatif memiliki ide kreatif (Persuasif) termasuk dalam kategori baik.

Tabel 3. Kepala Sekolah Komunikatif

\begin{tabular}{cccccccc}
\hline $\begin{array}{c}\text { Alternatif } \\
\text { Jawaban }\end{array}$ & Bobot & Frekuensi & $\begin{array}{c}\text { Skor } \\
\text { Capaian }\end{array}$ & $\begin{array}{c}\text { Persentase } \\
(\%)\end{array}$ & $\begin{array}{c}\text { Skor } \\
\text { Maksimal }\end{array}$ & $\begin{array}{c}\text { Persentase } \\
\text { Pernyataan }\end{array}$ & Kategori \\
\hline Selalu & 5 & 13 & 65 & 34,21 & & & \\
Sering & 4 & 16 & 64 & 42,11 & & & \\
Kadang & 3 & 8 & 24 & 21,05 & 190 & $81,58 \%$ & Baik \\
Jarang & 2 & 1 & 2 & 2,63 & & & \\
Tidak & 1 & 0 & 0 & 0,00 & & \\
Pernah & & 38 & 155 & 100,00 & & \\
Total & & \multicolumn{7}{c}{ (Sumber: Data diolah, 2020) } & & \\
\hline \multicolumn{7}{c}{}
\end{tabular}

Tabel 3 menggambarkan bahwa responden yang menyatakan Selalu memiliki frekuensi sebesar 13 atau 34,21\%, responden yang menyatakan Sering memiliki frekuensi sebesar 16 atau $42,11 \%$, responden yang menyatakan Kadang-kadang memiliki frekuensi sebesar 8 atau 21,05\%, responden yang menyatakan Jarang memiliki frekuensi sebesar 1 atau $2,63 \%$, sedangkan Tidak pernah memiliki frekuensi sebesar 0 atau $0,00 \%$. Dengan demikian hasil penelitian ini menunjukkan bahwa jawaban sering merupakan pilihan jawaban yang paling banyak dipilih oleh responden yaitu sebanyak $42,11 \%$.

Dari hasil analisis skor data diatas maka dapat diperoleh persentase $81,58 \%$, jika dilihat dari Tabel 3 bahwa kepala sekolah yang komunikatif baik termasuk dalam kategori baik.

Tabel 4. Kepala Sekolah Menginspirasi

\begin{tabular}{cccccccc}
\hline $\begin{array}{c}\text { Alternatif } \\
\text { Jawaban }\end{array}$ & Bobot & Frekuensi & $\begin{array}{c}\text { Skor } \\
\text { Capaian }\end{array}$ & $\begin{array}{c}\text { Persentase } \\
(\%)\end{array}$ & $\begin{array}{c}\text { Skor } \\
\text { Maksimal }\end{array}$ & $\begin{array}{c}\text { Persentase } \\
\text { Pernyataan }\end{array}$ & Kategori \\
\hline Selalu & 5 & 1 & 60 & 31,58 & & & \\
Sering & 4 & 19 & 76 & 50,00 & & & \\
Kadang & 3 & 7 & 21 & 18,42 & 190 & $82,63 \%$ & Baik \\
Jarang & 2 & 0 & 0 & 0,00 & & & \\
Tidak & 1 & 0 & 0 & 0,00 & & & \\
Pernah & & & & & & & \\
Total & & 38 & 157 & 100,00 & & & \\
\hline
\end{tabular}

(Sumber: Data diolah, 2020)

Tabel 4 menggambarkan bahwa responden yang menyatakan Selalu memiliki frekuensi sebesar 12 atau 31,58\%, responden yang menyatakan Sering memiliki frekuensi sebesar 19 atau 50,00\%, responden yang menyatakan Kadang-kadang memiliki frekuensi sebesar 7 atau 18,42\%, sedangkan Jarang dan Tidak pernah sebesar 0 atau 0,00\%. Dengan demikian hasil penelitian ini menunjukkan bahwa jawaban Sering merupakan pilihan jawaban yang paling banyak dipilih oleh responden yaitu sebanyak 50,00\%.

Dari hasil analisis skor data tabel 4, maka dapat diperoleh persentase 82,63\%. Jika dilihat dari Tabel 4 bahwa kepala sekolah menginspirasi bawahan dan orang lain secara jelas termasuk dalam kategori baik.

Tabel 5 menggambarkan bahwa responden yang menyatakan Selalu memiliki frekuensi sebesar 13 atau 34,21\%, responden yang menyatakan Sering memiliki frekuensi sebesar 17 atau 44,74\%, responden yang menyatakan Kadang-kadang memiliki frekuensi sebesar 8 atau 21,05\%, sedangkan Jarang dan Tidak pernah sebesar 0 atau 0,00\%. Dengan demikian hasil penelitian ini menunjukkan bahwa jawaban sering merupakan pilihan jawaban yang paling banyak dipilih oleh responden yaitu sebanyak $44,74 \%$. 
Tabel 5. Kepala Sekolah Berpikiran Terbuka

\begin{tabular}{cccccccc}
\hline $\begin{array}{c}\text { Alternatif } \\
\text { Jawaban }\end{array}$ & Bobot & Frekuensi & $\begin{array}{c}\text { Skor } \\
\text { Capaian }\end{array}$ & $\begin{array}{c}\text { Persentase } \\
(\%)\end{array}$ & $\begin{array}{c}\text { Skor } \\
\text { Maksimal }\end{array}$ & $\begin{array}{c}\text { Persentase } \\
\text { Pernyataan }\end{array}$ & Kategori \\
\hline Selalu & 5 & 13 & 65 & 34,21 & & & \\
Sering & 4 & 17 & 68 & 42,11 & & & \\
Kadang & 3 & 8 & 24 & 23,68 & 190 & $82,63 \%$ & Baik \\
Jarang & 2 & 0 & 0 & 23,68 & & & \\
Tidak & 1 & 0 & 0 & 0,00 & & & \\
Pernah & & & & & & & \\
Total & & 38 & 157 & 100,00 & & \\
\hline
\end{tabular}

(Sumber: Data diolah, 2020)

Dari hasil analisis skor data pada tabel 4, maka dapat diperoleh persentase $82,63 \%$. Jika dilihat dari Tabel 5 bahwa kepala sekolah berpikiran terbuka termasuk dalam kategori baik.

Tabel 6. Kepala sekolah Revolusioner

\begin{tabular}{cccccccc}
\hline $\begin{array}{c}\text { Alternatif } \\
\text { Jawaban }\end{array}$ & Bobot & Frekuensi & $\begin{array}{c}\text { Skor } \\
\text { Capaian }\end{array}$ & $\begin{array}{c}\text { Persentase } \\
(\%)\end{array}$ & $\begin{array}{c}\text { Skor } \\
\text { Maksimal }\end{array}$ & $\begin{array}{c}\text { Persentase } \\
\text { Pernyataan }\end{array}$ & Kategori \\
\hline Selalu & 5 & 15 & 75 & 39,47 & & & \\
Sering & 4 & 14 & 56 & 36,84 & & & \\
Kadang & 3 & 9 & 27 & 23,68 & 190 & $83,16 \%$ & Baik \\
Jarang & 2 & 0 & 0 & 0,00 & & & \\
Tidak & 1 & 0 & 0 & 0,00 & & \\
Pernah & & 38 & 156 & 100,00 & & \\
Total & & &
\end{tabular}

Tabel 6 menggambarkan bahwa responden yang menyatakan Selalu memiliki frekuensi sebesar 15 atau 39,47\%, responden yang menyatakan Sering memiliki frekuensi sebesar 14 atau 36,84\%, responden yang menyatakan Kadang-kadang memiliki frekuensi sebesar 9 atau 23,68\%, sedangkan Jarang dan Tidak pernah sebesar 0 atau 0,00\%. Dengan demikian hasil penelitian ini menunjukkan bahwa jawaban Selalu merupakan pilihan jawaban yang paling banyak dipilih oleh responden yaitu $39,47 \%$.

Dari hasil analisis skor data pada tabel 6, maka dapat diperoleh persentase 83,16\%. Jika dilihat dari Tabel 6 bahwa kepala sekolah meningkatkan revolusioner guru dan siswa termasuk dalam kategori baik.

Tabel 7. Kepala Sekolah Evolusioner

\begin{tabular}{cccccccc}
\hline $\begin{array}{c}\text { Alternatif } \\
\text { Jawaban }\end{array}$ & Bobot & Frekuensi & $\begin{array}{c}\text { Skor } \\
\text { Capaian }\end{array}$ & $\begin{array}{c}\text { Persentase } \\
(\%)\end{array}$ & $\begin{array}{c}\text { Skor } \\
\text { Maksimal }\end{array}$ & $\begin{array}{c}\text { Persentase } \\
\text { Pernyataan }\end{array}$ & Kategori \\
\hline Selalu & 5 & 12 & 60 & 31,58 & & & \\
Sering & 4 & 11 & 44 & 28,95 & & & \\
Kadang & 3 & 15 & 45 & 39,47 & 190 & $78,42 \%$ & Baik \\
Jarang & 2 & 0 & 0 & 0,00 & & & \\
Tidak Pernah & 1 & 0 & 0 & 0,00 & & & \\
Total & & 38 & 156 & 100,00 & & \\
\hline \multicolumn{7}{c}{ (Sumber: Data diolah, 2020) }
\end{tabular}

Tabel 7 menggambarkan bahwa responden yang menyatakan Selalu memiliki frekuensi sebesar 12 atau 31,58\%, responden yang menyatakan Sering memiliki frekuensi sebesar 11 atau 28,95\%, responden yang menyatakan Kadang-kadang memiliki frekuensi sebesar 15 atau 39,47\%, sedangkan Jarang dan tidak pernah sebesar 0 atau 0,00\%. Dengan 
demikian hasil penelitian ini menunjukkan bahwa jawaban Kadang-kadang merupakan pilihan jawaban yang paling banyak dipilih oleh responden yaitu sebanyak $39,47 \%$.

Dari hasil analisis skor data pada tabel 7, maka dapat diperoleh persentase 78,42\%. Jika dilihat dari Tabel 7 bahwa kepala sekolah menjalankan evolusioner secara efektif dan efisien termasuk dalam kategori baik.

Tabel 8. Kepala Sekolah Memotivasi Tim Adaptif Perubahan

\begin{tabular}{cccccccc}
\hline $\begin{array}{c}\text { Alternatif } \\
\text { Jawaban }\end{array}$ & Bobot & Frekuensi & $\begin{array}{c}\text { Skor } \\
\text { Capaian }\end{array}$ & $\begin{array}{c}\text { Persentase } \\
(\%)\end{array}$ & $\begin{array}{c}\text { Skor } \\
\text { Maksimal }\end{array}$ & $\begin{array}{c}\text { Persentase } \\
\text { Pernyataan }\end{array}$ & Kategori \\
\hline Selalu & 5 & 12 & 60 & 31,58 & & & \\
Sering & 4 & 12 & 48 & 31,58 & & \\
Kadang & 3 & 11 & 33 & 28,95 & 190 & $77,37 \%$ & Baik \\
Jarang & 2 & 3 & 6 & 7,89 & & & \\
Tidak & 1 & 0 & 0 & 0,00 & & \\
Pernah & & 38 & 147 & 100,00 & & \\
Total & & &
\end{tabular}

Tabel 8 menggambarkan bahwa responden yang menyatakan Selalu memiliki frekuensi sebesar 12 atau 31,58\%, responden yang menyatakan Sering memiliki frekuensi sebesar 12 atau 31,58\%, responden yang menyatakan Kadang-kadang memiliki frekuensi sebesar 11 atau 28,95\%, dan responden yang menyatakan Jarang memiliki frekuensi sebesar 3 atau 7,89\%, sedangkan Tidak Pernah memiliki frekuensi sebesar 0 atau 0,00\%. Dengan demikian hasil penelitian ini menunjukkan bahwa jawaban Selalu dan Sering merupakan pilihan jawaban yang paling banyak dipilih oleh responden yaitu sebanyak $31,58 \%$.

Dari hasil analisis skor data pada tabel 8, maka dapat diperoleh persentase 77,37\%. Jika dilihat dari Tabel 8 bahwa kepala sekolah meningkatkan motivasi tim yang adaptif perubahan yang berkualitas termasuk dalam kategori baik.

Tabel 9. Kepala Sekolah Bekerjasama Memajukan Tim

\begin{tabular}{cccccccc}
\hline $\begin{array}{c}\text { Alternatif } \\
\text { Jawaban }\end{array}$ & Bobot & Frekuensi & $\begin{array}{c}\text { Skor } \\
\text { Capaian }\end{array}$ & $\begin{array}{c}\text { Persentase } \\
(\%)\end{array}$ & $\begin{array}{c}\text { Skor } \\
\text { Maksimal }\end{array}$ & $\begin{array}{c}\text { Persentase } \\
\text { Pernyataan }\end{array}$ & Kategori \\
\hline Selalu & 5 & 14 & 70 & 34,21 & & & \\
Sering & 4 & 16 & 64 & 42,11 & & & Baik \\
Kadang & 3 & 8 & 24 & 23,68 & 190 & $82,11 \%$ & \\
Jarang & 2 & 0 & 0 & 23,68 & & & \\
Tidak & 1 & 0 & 0 & 0,00 & & \\
Pernah & & 38 & 158 & 100,00 & \\
Total & & & & & \\
\hline & & &
\end{tabular}

Tabel 9 menggambarkan bahwa responden yang menyatakan Selalu memiliki frekuensi sebesar 14 atau 36,84\%, responden yang menyatakan Sering memiliki frekuensi sebesar 16 atau 42,11\%, responden yang menyatakan Kadang-kadang memiliki frekuensi sebesar 8 atau 21,05\%, sedangkan responden yang menyatakan Jarang dan Tidak pernah memiliki frekuensi sebesar 0 atau $0,00 \%$. Dengan demikian hasil penelitian ini menunjukkan bahwa jawaban Sering merupakan pilihan jawaban yang paling banyak dipilih oleh responden yaitu sebanyak $42,11 \%$.

Dari hasil analisis skor data pada tabel 9, maka dapat diperoleh persentase 83,16\%. Jika dilihat dari Tabel 9 bahwa kepala sekolah memiliki tingkat bekerjasama memajukan tim untuk keberhasilan dalam menciptakan sekolah yang aman sehat dan baik termasuk dalam kategori baik. 
Tabel 10. Kepala Sekolah Evaluatif

\begin{tabular}{cccccccc}
\hline $\begin{array}{c}\text { Alternatif } \\
\text { Jawaban }\end{array}$ & Bobot & Frekuensi & $\begin{array}{c}\text { Skor } \\
\text { Capaian }\end{array}$ & $\begin{array}{c}\text { Persentase } \\
(\%)\end{array}$ & $\begin{array}{c}\text { Skor } \\
\text { Maksimal }\end{array}$ & $\begin{array}{c}\text { Persentase } \\
\text { Pernyataan }\end{array}$ & Kategori \\
\hline Selalu & 5 & 5 & 25 & 13,16 & & & \\
Sering & 4 & 16 & 64 & 42,11 & & & \\
Kadang & 3 & 17 & 51 & 44,74 & 190 & $73,68 \%$ & Baik \\
Jarang & 2 & 0 & 0 & 0,00 & & & \\
Tidak & 1 & 0 & 0 & 0,00 & & & \\
Pernah & & 38 & 140 & 100,00 & & & \\
Total & & 38 & &
\end{tabular}

(Sumber: Data diolah, 2020)

Tabel 10 menggambarkan bahwa responden yang menyatakan Selalu memiliki frekuensi sebesar 5 atau 13,16\%, responden yang menyatakan Sering memiliki frekuensi sebesar 16 atau 42,11\%, responden yang menyatakan Kadang-kadang memiliki frekuensi sebesar 17 atau 44,74\%, sedangkan responden yang menyatakan Jarang dan Tidak pernah memiliki frekuensi sebesar 0 atau 0,00\%. Dengan demikian hasil penelitian ini menunjukkan bahwa jawaban Kadang-kadang merupakan pilihan jawaban yang paling banyak dipilih oleh responden yaitu sebanyak $44,74 \%$.

Dari hasil analisis skor data pada tabel 10, maka dapat diperoleh persentase 73,68\%. Jika dilihat dari Tabel 10 bahwa kepala sekolah yang evaluatif/bekerja tim merancang penilaian pembelajaran menjadikan sekolah yang berkualitas termasuk dalam kategori baik.

Tabel 11. Kepala Sekolah Adaptif Teknologi untuk Akselerasi Merdeka Belajar Menciptakan SDM yang Unggul Akselerasi

\begin{tabular}{cccccccc}
\hline $\begin{array}{c}\text { Alternatif } \\
\text { Jawaban }\end{array}$ & Bobot & Frekuensi & $\begin{array}{c}\text { Skor } \\
\text { Capaian }\end{array}$ & $\begin{array}{c}\text { Persentase } \\
(\%)\end{array}$ & $\begin{array}{c}\text { Skor } \\
\text { Maksimal }\end{array}$ & $\begin{array}{c}\text { Persentase } \\
\text { Pernyataan }\end{array}$ & Kategori \\
\hline Selalu & 5 & 5 & 25 & 13,16 & & & \\
Sering & 4 & 12 & 48 & 31,58 & & $70,53 \%$ & Baik \\
Kadang & 3 & 19 & 57 & 50,00 & 190 & & \\
Jarang & 2 & 2 & 4 & 5,26 & & & \\
Tidak & 1 & 0 & 0 & 0,00 & & \\
Pernah & & 38 & 134 & 100,00 & \\
Total & & &
\end{tabular}

Tabel 11 menggambarkan bahwa responden yang menyatakan Selalu memiliki frekuensi sebesar 5 atau 13,16\%, responden yang menyatakan Sering memiliki frekuensi sebesar 12 atau 31,58\%, responden yang menyatakan Kadang-kadang memiliki frekuensi sebesar 19 atau 50,00\%, dan responden yang menyatakan Jarang memiliki frekuensi sebesar 2 atau $5,26 \%$, sedangkan responden yang menyatakan Tidak pernah memiliki frekuensi sebesar 0 atau $0,00 \%$. Dengan demikian hasil penelitian ini menunjukkan bahwa jawaban Kadangkadang merupakan pilihan jawaban yang paling banyak dipilih oleh responden yaitu sebanyak $50,00 \%$.

Dari hasil analisis skor data pada tabel 11, maka dapat diperoleh persentase 70,53\%. Jika dilihat dari Tabel 11 bahwa kepala sekolah menciptakan SDM yang unggul termasuk dalam kategori baik.

Dari indikator-indikator yang telah dianalisis dapat disimpulkan bahwa kepala sekolah mampu mengembangkan Manajemen Kepemimpinan Inovatif melalui pola pembelajaran inovatif dalam mengembangkan strategi mengenai visi, misi, tujuan sekolah, dan program yang terencana melalui fungsi manajemen kepemimpinan inovatif dalam perspektif merdeka belajar dengan kriteria yang di capai dari hasil berada pada kategori Baik 

DOI: 10.31004/obsesi.v5i2.901

dengan nilai skor rata-rata 151 dengan kategori yang telah ditentukan. Untuk itu, kepala sekolah yang memiliki pola Manajemen Kepemimpinan Inovatif dapat mewujudkan panduan yang tersistem dan terstruktur melalui kurikulum yang diwujudkan dalam visi, misi, tujuan, dan program sekolah bisa lebih dikembangkan lagi sehingga di masa yang akan datang semakin lebih baik (Ramli, 2017).

Tabel 12. Rekapitulasi Manajemen Kepemimpinan Inovatif

\begin{tabular}{|c|c|c|c|c|}
\hline $\begin{array}{l}\text { No. } \\
\text { Tabel }\end{array}$ & Pernyataan & Skor & Persentase & Kategori \\
\hline 2 & $\begin{array}{l}\text { Kepala sekolah persuasif/memiliki gagasan ide } \\
\text { kreatif. }\end{array}$ & 156 & $82,11 \%$ & Baik \\
\hline 3 & $\begin{array}{l}\text { Kepala sekolah komunikatif/dapat menyelesaikan hal } \\
\text { sulit masalah organisasi. }\end{array}$ & 155 & $81,58 \%$ & Baik \\
\hline 4 & Kepala sekolah menginspirasi. & 157 & $82,63 \%$ & Baik \\
\hline 5 & $\begin{array}{l}\text { Kepala sekolah berpikiran terbuka menerima saran } \\
\text { dan pendapat. }\end{array}$ & 157 & $82,63 \%$ & Baik \\
\hline 6 & $\begin{array}{l}\text { Kepala sekolah revolusioner yang mampu menerima } \\
\text { dan mengimplementasikan perubahan. }\end{array}$ & 158 & $83,16 \%$ & Baik \\
\hline 7 & $\begin{array}{l}\text { Kepala sekolah evolusioner yang berjiwa menerima } \\
\text { perubahan dengan cara-cara baru. }\end{array}$ & 149 & $78,42 \%$ & Baik \\
\hline 8 & Kepala sekolah memotivasi tim adaptif perubahan. & 147 & $77,37 \%$ & Baik \\
\hline 9 & Kepala sekolah Bekerjasama memajukan tim. & 158 & $83,16 \%$ & Baik \\
\hline 10 & $\begin{array}{l}\text { Kepala sekolah evaluatif/bekerja tim merancang } \\
\text { penilaian pembelajaran. }\end{array}$ & 140 & $73,68 \%$ & Baik \\
\hline \multirow[t]{2}{*}{11} & $\begin{array}{l}\text { Kepala sekolah adaptif teknologi untuk akselarasi } \\
\text { merdeka belajar. }\end{array}$ & 134 & $70,53 \%$ & Baik \\
\hline & $\begin{array}{c}\text { Jumlah } \\
\text { Rata-Rata }\end{array}$ & $\begin{array}{c}1.511 \\
151\end{array}$ & $79,53 \%$ & Baik \\
\hline
\end{tabular}

(Sumber: Data diolah, 2020)

Berdasarkan penjelasan sebelumnya, maka dapat disusun histogram pada gambar 2 untuk menggambarkan indikator kepala sekolah mewujudkan visi, misi, dan tujuan sekolah.

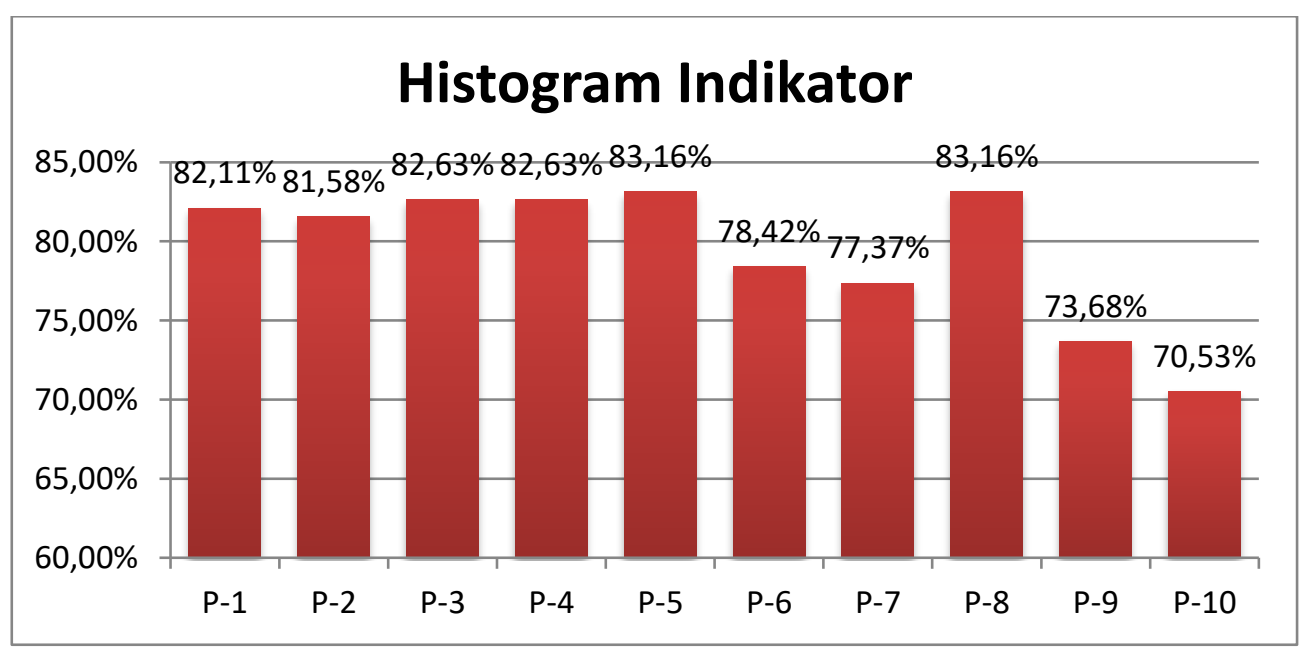

\section{Gambar 2. Kepala Sekolah Inovatif dalam Perspektif Merdeka Belajar di Era New Normal}

Rekapitulasi hasil indikator persentase manajemen kepemimpinan inovatif berada pada kategori Baik dengan nilai persentase 79,53 \%, yang artinya kepala sekolah memiliki jiwa revolusioner yang mampu menerima dan mengimplementasikan perubahan melalui visi, misi, dan tujuan untuk mengembangkan sekolah. Hal ini sejalan dengan hasil penelitian yang 
dilakukan oleh (Jannah, 2020) yang menyatakan bahwa Kepala sekolah harus memiliki visi dan misi ke depan, percaya diri, mampu mengkomunikasikan ide, dapat diteladani, mempunyai idealisme, inspirasi, memiliki kemampuan mempengaruhi dan mampu menghargai perbedaan untuk dirubah menjadi suatu kekuatan bersama.

Kepala sekolah harus lebih meningkatkan lagi kemampuannya untuk pengembangan sekolah sehingga sekolah dapat mengeluarkan siswa yang berkualitas karena dengan adanya kepala sekolah yang adaptif teknologi untuk akselerasi merdeka belajar dapat mewujudkan visi dan tujuan yang baik, maka sekolah akan mendapatkan pengakuan kepemimpinan kepala sekolah yang memiliki inovatif efektif (Hendri, 2020). Hal tersebut sejalan juga dengan hasil penelitian yang dilakukan oleh (Ja'far, 2019) yang menyatakan bahwa konsep kepemimpinan inovatif mengarah kepada kepemimpinan yang efektif yakni kepemimpinan yang menjadi panutan, perintis, penyelaras, dan pembudaya sehingga melahirkan pemimpin yang memiliki prinsip kuat dan berkarakter. Seseorang dikatakan inovatif apabila memiliki ciri-ciri sebagai berikut: 1. Mengerjakan tugas dengan cara yang tidak konvensional; 2. Menemukan masalah dan memecahkannya dengan cara yang tidak linier; 3. Lebih tertarik pada hasil dari pada proses; 4. Tidak senang pada pekerjaan yang bersifat rutin; 5. Kurang senang pada kesepakatan; dan 6. Kurang sensitif terhadap orang lain. Oleh karena itu, kepala sekolah harus memperhatikan kepemimpinan visioner dalam mewujudkan merdeka belajar melalui visi, tujuan, dan program yang inovatif supaya sekolah lebih berkembang dan berkualitas dimasa yang akan datang (Yamin \& Syahrir, 2020).

Kepemimpinan inovatif harus dapat mengembangkan hal-hal sebagai berikut: a) Ide generasi; b) Evaluasi; c) Penerapan (Implementasi). Kedua jenis inovasi tersebut termasuk inovasi eksplorasi yang melibatkan dan menghasilkan ide-ide baru, dan inovasi nilai tambah yang melibatkan modifikasi dan peningkatan ide-ide yang sudah ada sebelumnya. Hal tersebut sejalan dengan hasil penelitian (Ja'far, 2019) yang juga mengungkapkan bahwa mempunyai ide dan inisiatif yang baik untuk kemajuan dan pengembangan sekolah harus dimulai dari ide kepala sekolah. Hal tersebut merupakan sifat-sifat dan kepribadian seorang pemimpin. Sifat-sifat dan kepribadian yang harus dimiliki seorang pemimpin sebagai berikut: 1. Jujur; 2. percaya diri; 3. tanggung jawab; 4 . berani mengambil risiko dan keputusan; 5 . berjiwa besar; 6 . emosi yang stabil dan teladan.

Pengaruh pemimpin inovatif dapat mengelola dan mengambil keputusan untuk fase evaluasi, mulai pada tahap perencanaan, pengelolaan, pengembangan indikator menjadi program inti kepemimpinan yang inovatif dalam pembelajaran merdeka belajar dengan memperhatikan adaptasi informasi teknologi yang responsif untuk implementasi dan aplikatif. Hal ini juga sejalan dengan hasil penelitian (Budiana, 2015) yang mengungkapkan bahwa secara umum para kepala sekolah terlihat antusias mengikuti kegiatan pelatihan informasi teknologi, terlebih bagi guru-guru yang menyadari betul bahwa TIK sangat berguna dalam membantu pembelajaran. Mereka merasa terbantu dengan adanya kegiatan pelatihan ini sebagai sarana untuk menambah motivasi, pengetahuan, pemahaman dan keterampilan dalam memanfaatkan TIK bagi pembelajaran. Semua pihak, khususnya para guru peserta pelatihan menyadari bahwa dengan pelatihan singkat semacam ini tidak mungkin para guru dapat menguasai TIK dalam pembelajaran dengan baik, terutama bagi mereka yang sama sekali tidak pernah menggunakan TIK, akan tetapi setidaknya melalui pelatihan yang berkelanjutan akan menumbuhkan motivasi dan pengetahuan akan manfaat TIK bagi pembelajaran, yang dapat ditularkan sebagai motivasi kepada para siswa untuk melek teknologi.

Model yang digunakan tidak boleh dilihat dalam "mode lock-step" yang mempengaruhi maju dan mundurnya aktivitas kepala sekolah yang inovatif dalam perspektif merdeka belajar di era new normal, namun dapat dilihat melalui tahapan step yang sistematis melalui ide yang dihasilkan, didiskusikan, dan diuji untuk input informasi sistem yang berawal secara berproses. Hal ini sejalan juga dengan hasil penelitian yang dilakukan oleh (Herawan, 2017) yang menjelaskan bahwa seorang kepala sekolah jika dalam menjalankan 
fungsi kepemimpinannya berorientasi kepada masalah pembelajaran, ini menunjukkan bahwa ia sedang menjalani peran sebagai pemimpin pembelajaran. Oleh karena itu, dalam menjalankan peran ini kepala sekolah akan menaruh perhatian yang tinggi pada masalah kurikulum, proses belajar mengajar, penilaian hasil belajar serta pengembangan guru.

Kepemimpinan pembelajaran merupakan upaya memimpin para guru agar mengajar lebih baik, yang pada gilirannya dapat memperbaiki prestasi belajar siswa. Kepemimpinan pembelajaran atau kepemimpinan instruksional adalah kepemimpinan yang memfokuskan dan menekankan pada pembelajaran yang komponen-komponennya meliputi kurikulum, proses belajar mengajar, asesmen (penilaian hasil belajar), penilaian serta pengembangan guru, layanan prima dalam pembelajaran, dan pembangunan komunitas belajar di sekolah. Kepemimpinan pembelajaran sebagai berikut:(1) kepala sekolah mensosialisasikan dan menanamkan isi dan makna visi sekolahnya dengan baik; (2) kepala sekolah melibatkan pemangku kepentingan dalam pengelolaan sekolah; (3) kepala sekolah memberikan dukungan kepada pembelajaran; (4) kepala sekolah melakukan pemantauan terhadap proses belajar mengajar dan (5) kepala sekolah berperan sebagai fasilitator.

Tujuan utama kepemimpinan pembelajaran adalah memberikan layanan prima kepada semua siswa agar mereka mampu mengembangkan potensi kualitas dasar dan kualitas instrumentalnya untuk menghadapi masa depan yang belum diketahui dan sarat dengan tantangan yang sangat turbulen. Lebih lanjut dikemukakan pada dasarnya kepemimpinan pembelajaran untuk memfasilitas pembelajaran agar siswanya bisa meningkat prestasi belajarnya, meningkatnya kepuasan belajarnya, meningkat motivasi belajar, meningkat keingintahuannya, kreativitasnya, inovasinya, jiwa kewirausahaannya, dan meningkat kesadarannya untuk belajar secara terus-menerus sepanjang hayat karena ilmu pengetahuan dan teknologi serta seni berkembang dengan pesat.

Banyak tugas yang harus dilakukan oleh kepala sekolah sebagai penanggung jawab penyelenggaraan pendidikan di sekolah, yaitu sebagai manajer, supervisor, dan sebagai pemimpin. Mengingat tugas yang bersifat administrasi dan manajerial begitu banyak yang harus dilakukan oleh kepala sekolah, maka sebagian besar waktu dan tenaganya tercurah untuk menyelesaikan tugas yang terkait dengan masalah manajerial tersebut. Hasil penelitian (Ja'far, 2019) menunjukkan bahwa seluruh dari pekerjaan yang harus dilaksanakan oleh kepala sekolah hanya $10 \%$ persen yang dialokasikan untuk kepemimpinan pembelajaran. Alasannya diantaranya adalah banyak kegiatan administrasi yang dilaksanakan. Padahal kepemimpinan yang berfokus pada pembelajaran saat ini perlu mendapatkan perhatian, hal ini karena pada umumnya masyarakat senantiasa menuntut layanan pembelajaran yang berkualitas yang diberikan oleh sekolah melalui kegiatan pembelajaran yang dilakukan oleh para guru.

Berdasarkan penjelasan diatas, maka kepala sekolah yang inovatif dapat menyelesaikan ide dan gagasan melalui implementasi fungsi menajemen secara bertahap dan tersistem, mulai dari awal perencanaan sampai pada akhir dievaluasi bersama. Jika tidak baik diperbaiki, jika baik dilanjutkan, dan ditingkatkan. Hal ini harus bekerjasama bersama tim melalui kreativitas tim dan inovasi organisasi, serta cara kerja tersistem dalam inovasi organisasi melalui kreativitas individu secara visualiasasi yang paham akan informasi aktual secara digital.

\section{SIMPULAN}

Manajemen kepemimpinan inovatif pada pendidikan anak usia dini dalam perspektif merdeka belajar era new normal di Kota Gorontalo Provinsi Gorontalo menunjukkan hasil indikator persentase manajemen kepemimpinan inovatif berada pada kategori Baik dengan nilai persentase 79,53 \%, yang artinya kepala sekolah memiliki jiwa revolusioner yang mampu menerima dan mengimplementasikan perubahan melalui visi, misi, dan tujuan untuk mengembangkan sekolah. Pola model manajemen kepemimpinan inovatif yang dilakukan 
merupakan proses inovasi yang menggunakan kepemimpinan langsung dan tindakan langsung.

\section{UCAPAN TERIMA KASIH}

Tim penulis mengucapkan terima kasih kepada Universitas Negeri Gorontalo dan Pendidikan Anak Usia Dini yang telah memberi dukungan terhadap terlaksananya penelitian ini. Tim penulis juga mengucapkan terima kasih kepada Pengelola Jurnal Obsesi yang telah memberi review dan memberi masukan atas terbitnya artikel ini.

\section{DAFTAR PUSTAKA}

Budiana. (2015). Pemanfaatan Teknologi Informasi dan Komunikasi dalam Pembelajaran bagi Para Guru SMP N 2 Kawali Desa Citereup Kabupten Ciamis. Jurnal Aplikasi Ipteks Untuk Masyarakat Universitas Padjajaran, 4(1), 59-62.

Candra, A., Sabandi, A., Syahril, S., \& Zikri, A. (2020). Kontribusi Kepemimpinan Kepala Sekolah dan Insentif terhadap Motivasi Berprestasi Guru. Jurnal Basicedu, 4(3), 690-695. https:// doi.org/10.31004/basicedu.v4i3.379

Dewi, I., \& Suryana, D. (2020). Analisis Evaluasi Kinerja Pendidik Pendidikan Anak Usia Dini di PAUD Al Azhar Bukittinggi. Jurnal Obsesi: Jurnal Pendidikan Anak Usia Dini, 4(2), 1051. https://doi.org/10.31004/obsesi.v4i2.465

Djafri, N. (2020). Pengaruh Gaya Kepemimpinan dan Budaya Kerja Kepala Sekolah di Pendidikan Anak Usia Dini. Jurnal Obsesi : Jurnal Pendidikan Anak Usia Dini, 4(2), 940. https:// doi.org/10.31004/obsesi.v4i2.494

Fauziddin, M., \& Mufarizuddin, M. (2018). Useful of Clap Hand Games for Optimalize Cogtivite Aspects in Early Childhood Education. Jurnal Obsesi : Jurnal Pendidikan Anak Usia Dini, 2(2), 162. https:/ / doi.org/10.31004/obsesi.v2i2.76

Hendri, N. (2020). Merdeka Belajar; Antara Retorika dan Aplikasi. E-Tech: Jurnal Ilmiah Teknologi Pendidikan, 08(01). http://ejournal.unp.ac.id/index.php/etech/article/view/107288

Herawan, E. (2017). Kinerja Kepala Sekolah sebagai Instructional Leader. PEDAGOGIA Jurnal Ilmu Pendidikan, 13(3), 167. https:/ / doi.org/10.17509/pedagogia.v13i3.6002

Ideswal, I., Yahya, Y., \& Alkadri, H. (2020). Kontribusi Iklim Sekolah dan Kepemimpinan Kepala Sekolah terhadap Kinerja Guru Sekolah Dasar. Jurnal Basicedu, 4(2), 460-466. https:// doi.org/10.31004/basicedu.v4i2.381

Ja'far, J. (2019). Inovasi Kepemimpinan Kepala Madrasah Kreatif dalam Meningkatkan Mutu $\begin{array}{lllll}\text { Pendidikan di Sekolah. Journal EVALUASI, } & 74 .\end{array}$ https:/ / doi.org/10.32478/evaluasi.v3i1.215

Jannah, L. K. (2020). Kepemimpinan Kepala Sekolah dalam Menghadapi Era Revolusi Industri 4.0: Perspektif Manajemen Pendidikan. ISLAMIKA, 2(1), 129-139. https:/ / doi.org/10.36088/islamika.v2i1.471

Mustaghfiroh, S. (2020). Konsep "Merdeka Belajar" Perspektif Aliran Progresivisme John Dewey. Jurnal Studi Guru Dan Pembelajaran, 3(1 SE-Articles), 141-147. https://ejournal.my.id/jsgp/article/view/248

Nurdin, N., \& Anhusadar, L. O. (2020). Evaluasi Pelaksanaan Standar Proses di Satuan Pendidikan Anak Usia Dini. Jurnal Obsesi : Jurnal Pendidikan Anak Usia Dini, 4(2), 982. https:// doi.org/10.31004/obsesi.v4i2.485

Paudi, S., \& Suking, A. (2020). Kinerja Wakil Kepala Sekolah Menengah Pertama dilihat dari Tugas Pokok dan Fungsinya. Jurnal Manajemen Pendidikan: Jurnal Ilmiah Administrasi, Manajemen Dan Kepemimpinan Pendidikan, 2(2), 192-205.

Ramli, M. (2017). Kepemimpinan Inovatif Dalam Implementasi Kebijakan Strategis Pemerintah Kota Makassar. JPP (Jurnal Politik Profetik), 5(2), 168-184. http://journal.uin-alauddin.ac.id/index.php/jpp/article/view/4343

Supriadi, O. (2020). Peranan Kepala PAUD dalam Penyelenggaraan Pendidikan Sebelum dan 
DOI: $10.31004 /$ obsesi.v5i2.901

Saat Terjadi Pandemi Covid-19. Jurnal Obsesi : Jurnal Pendidikan Anak Usia Dini, 5(1), 841-856. https://doi.org/10.31004/obsesi.v5i1.727

Utiarahman, P. (2017). Manajemen Program Akreditasi Pada Sekolah Menengah Pertama Negeri Di Kabupaten Boalemo. Jurnal Pascasarjana, 2(1), 124-129.

Wijoyo, H., \& Indrawan, I. (2020). Model Pembelajaran Menyongsong New Era Normal pada Lembaga PAUD di Riau. Jurnal Sekolah, 4(3), 205-212. https://doi.org/10.24114/js.v4i3.18526

Witarsa, R., \& Dista, D. X. (2019). Analisis Jawaban Siswa Usia 6 sampai 8 tahun terhadap Pembelajaran Sains Kreatif. Jurnal Obsesi : Jurnal Pendidikan Anak Usia Dini, 4(1), 58. https://doi.org/10.31004/obsesi.v4i1.288

Yamin, M., \& Syahrir, S. (2020). Pembangunan Pendidikan Merdeka Belajar (Telaah Metode Pembelajaran). Jurnal Ilmiah Mandala Education, 6(1), 126-136. https://doi.org/10.36312/jime.v6i1.1121

Yati, F., \& Yaswinda, Y. (2019). Penerapan Model Evaluasi CIPPO dalam Mengevaluasi Penyelenggaraan Lembaga PAUD. Jurnal Obsesi : Jurnal Pendidikan Anak Usia Dini, 4(1), 30. https:// doi.org/10.31004/obsesi.v4i1.238 